\title{
Estuaries and Nutrients
}




\section{Contemporary Issues in Science and Society}

Estuaries and Nutrients, edited by Bruce J. Neilson and $L$. Eugene Cronin, 1981

Pesticides: Contemporary Roles in Agriculture, Health, and the Environment, edited by $T$. J. Sheets and David Pimentel, 1979

Solar Energy: Chemical Conversion and Storage, edited by Richard R. Hautala, R. Bruce King, and Charles Kutal, 1979 

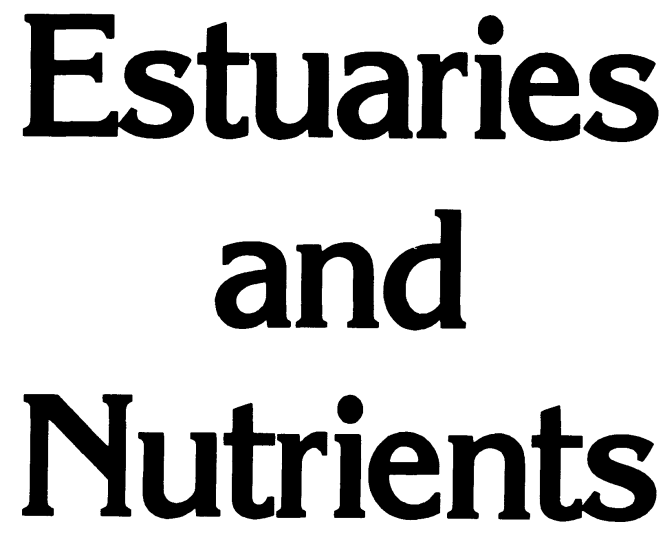

Edited by

\section{Bruce J. Neilson}

Virginia Institute of Marine Science and

L. Eugene Cronin Chesapeake Research Consortium

Humana Press · Clifton, New Jersey 
Copyright 1981, by The Humana Press Inc. Softcover reprint of the hardcover Ist edition 1981

All rights reserved

No part of the book may be reproduced in any form, by photostat, microfilm, or any other means, without written permission from the Publishers, except that the book and all its contents may be reproduced for any publication of the U.S. Government. This is in recognition of the financial support provided under Grant No. R 806189010 to the Chesapeake Research Consortium from the Environmental Protection Agency.

The Humana Press Inc.

Crescent Manor

PO Box 2148

Clifton, New Jersey 07015

\section{Library of Congress Cataloging in Publication Data}

International Symposium on the Effects of Nutrient Enrichment in Estuaries (1979: Williamsburg,

Va.)

Estuaries and Nutrients.

(Contemporary issues in science and society) (Chesapeake Research Consortium publication; no. 90)

"Proceedings of an International Symposium on the Effects of Nutrient Enrichment in Estuaries, Williamsburg, Virginia, 29-31, May, 1979, conducted by the Chesapeake Research Consortium for the Chesapeake Bay Program, United States Environmental Protection Agency"-Verso t.p.

Bibliography: $\mathrm{p}$.

Includes Index.

1. Estuarine ecology-Congresses. 2. Eutrophication-Congresses. 3. Estuarine pollutionCongresses. I. Neilson, Bruce J. II. Cronin, L. Eugene (Lewis Eugene), 1917- . III. Chesapeake Research Consortium. IV. United States. Environmental Protection Agency. Chesapeake Bay Program. V. Series. VII. Series: Chesapeake Research Consortium publication; no. 90.

$\begin{array}{lcc}\text { QH541.5.E8I57 } 1979 & 574.526365 & \begin{array}{l}81-83901 \\ \text { AAOR2 }\end{array} \\ & & \text { e-ISBN-13: } 978-1-4612-5826-1\end{array}$

DOI: $10.1007 / 978-1-4612-5826-1$ 


\section{CONTENTS}

Preface

ix

\section{Invited Review Papers}

Special Characteristics of Estuaries

Robert B. Biggs and L. Eugene Cronin

Conceptual Models and Processes of Nutrient Cycling in Estuaries Kenneth L. Webb

Physical and Geological Processes

Controlling Nutrient Levels in Estuaries Donald W. Pritchard and Jerry R. Schubel

Studies of Eutrophication in Lakes and Their Relevance to the Estuarine Environment

D.W. Schindler

Sources of Nutrients and the Scale of Eutrophication

Problems in Estuaries

Norbert A. Jaworski

Remineralization and Nutrient Cycling

in Coastal Marine Ecosystems

Scott W. Nixon

Uptake of Major Nutrients by Estuarine Plants James J. McCarthy

Indicators and Indices of Estuarine Enrichment A.J. McErlean and Gale Reed

Modeling of Eutrophication in Estuaries Donald J. O'Connor

Nutrient Enrichment and Estuarine Health Rezneat M. Darnell and Thomas M. Soniat

Impact of Nutrient Enrichment on Water Uses John H. Ryther and Charles B. Officer

Management Implications of Nutrient Standards Michael A. Bellanca 
vi

\section{Case Studies}

The Effects of Treated Sewage Discharge on the Biota of Port Phillip Bay, Vicotria, Australia

D.M. Axelrad, G.C.B. Poore, G.H. Arndt,

J. Bauld, V. Brown, R.R.C. Edwards and N.J. Hickman

279

Estuaries and Coastal Lagoons of South Western Australia

Ernest P. Hodgkin and R.C. Lenanton

309

Eutrophication in the Peel-Harvey Estuarine

System, Western Australia

A.J. McComb, R.P. Atkins, P.B. Birch,

D.M. Gordon and R.J. Lukatelich

The Use of Nutrients, Salinity and Water Circulation Data as a Tool for Coastal Zone Planning

Y. Monbet, F. Manaud, P. Gentien, M. Pommepuy,

G.P. Allen, J.C. Salomon and J. L'Yavanc

Reversal of the Eutrophication Process: A Case Study

Gerald A. Moshiri, Nicholas G. Aumen and

William B. Krumpton

Responses of Kaneohe Bay, Hawaii, to

Relaxation of Sewage Stress

S.V. Smith

\section{Contributed Papers}

Nitrification in the Upper Tidal James River

Carl F. Cerco

Eutrophication Trends in the Water Quality of the

Rhode River (1971-1978)

David L. Correll

Aboveground Net Primary Productivity of Three Gulf Coast

Marsh Macrophytes in Artificially Fertilized Plots

Armando A. de la Cruz, Courtney T. Hackney and

Judy P. Stout

Nitrification and Production of $\mathrm{N}_{2} \mathrm{O}$ in the Potomac: Evidence for Variability

James W. Elkins, Steven C. Wofsy, Michael B. McElroy

and Warren A. Kaplan 
Photosynthesis, Extracellular Release, and Heterotrophy of

Dissolved Organic Matter in Rhode River Estuarine Plankton Maria A. Faust and Ryszard J. Chrost

Enrichment of a Subtropical Estuary with Nitrogen,

Phosphorus and Silica

Thomas H. Fraser and William H. Wilcox

A Suggested Approach for Developing Water Quality Criteria for Management of Eutrophication

Norbert A. Jaworski and Orterio Villa, Jr.

The Significance of Dredging and Dredged Material Disposal as a

Source of Nitrogen and Phosphorus for Estuarine Waters

R. Anne Jones and G. Fred Lee

The Effects of Sewage Discharge into a Wind-Induced Plume Front W.J. Kimmerer, T.W. Walsh and J. Hirota

Application of the OECD Eutrophication Modeling Approach to Estuaries

G. Fred Lee and R. Anne Jones

Phosphorus and Nitrogen Limited Phytoplankton Productivity in Northeastern Gulf of Mexico Coastal Estuaries

Vernon B. Meyers and Richard I. Iverson

\section{Contributed Complementary Studies in the York River}

Short Term Changes in the Vertical Salinity Distribution of the York River Estuary Associated with Neap-Spring Tidal Cycle

Leonard W. Haas, Frederick J. Holden and

Christopher S. Welch

Time Varying Hydrodynamics and Water Quality in an Estuary C.F. D'Elia, K.L. Webb and R.L. Wetzel

Inorganic Nitrogen Regeneration and Total Oxygen Consumption by the Sediments at the Mouth of the York River, Virginia, USA

William C. Phoel, K.L. Webb and C.F. D'Elia

Phytoplankton Response to a Stratification-Mixing Cycle in the York River Estuary during Late Summer

Leonard W. Haas, Steven J. Hastings and Kenneth L. Webb

Index 
viii

Animal Index

Plant Index 638

Waterbody Index

640

Subject Index

641 


\section{PREFACE}

Estuaries are eternally enriched. Their positions at the foot of watersheds and their convenience as receiving bodies for the wastes of cites, towns and farms results in continuous addition of nutrients - those elements and compounds which are essential for organic production. Such materials must be added to these complex bodies of water to sustain production, since there is a net loss of water and its contents to the oceans. Enrichment from land and the ocean and the subsequent cycling of the original chemicals or their derivatives contribute to the extraordinarily high values of estuaries for human purposes. Many estuaries are able to assimilate large quantities of nutrients despite the great fluctuations which occur with variations in the flow from tributaries. The nutrients can be stored, incorporated in standing crops of plants, released, cycled and exported - and the system frequently achieves high production of plants and and animals without creation of any undesirable results of enrichment.

Excessive enrichment with the same elements and compounds can, however, be highly detrimental to estuaries and their uses. Coastal cities are usually located on the estuaries which provided a harbor for them and which now receive partially treated sewage and other wastes from the expanding population and industrial activity. Conversion of woodlands to agricultural use and the extensive application of fertilizers have resulted in the flow of large quantities of nutrients down the hill or slopes and eventually into the estuary.

The results of excessive enrichment can be dramatic and serious. As phytoplankton populations increase, they can change qualitatively so that a rich system feeding many components in the food web becomes a jungle, with massive production of species of little value in the energy systems.

Recognition that nutrient loading into the Chesapeake Bay system had been and was the source of serious and extensive damage to parts of the estuary - and that the resident population is projected to double within a few decades - resulted in the identification of excessive enrichment as one of the three areas of principal attention in the 5-year Chesapeake Bay Program conducted by the U.S. Environmental Protection Agency in cooperation with the State of Maryland and the Commonwealths of Pennsylvania and Virginia. Under a grant to the Chesapeake Research Consortium, Inc., to develop the background for our present state of knowledge about enrichment of estuaries, an International Symposium on the Effects of Nutrient Enrichment in Estuaries was convened at Williamsburg, Virginia on May 29-31 of 1979. Forty-four papers were presented and discussed. Of these, thirty-three survived the rigors of review and editing, and the demands on the time of the authors, and are presented in this volume. 
Papers are arranged in four sets. Invited Review Papers were solicited from recognized experts in various aspects of estuarine enrichment to provide the overview and summary so necessary for the education of all scientists and managers concerned with nutrient questions. The series is presented as it was at the Symposium, with broad background papers followed by reviews in specific areas. Six Case Studies are reported to illustrate problems and experiences in several parts of the world. Contributed Papers included a variety of reports on recent research, with a group of four papers derived from an interesting cooperative approach to a single estuarine area.

We hope that these papers will be of value. That value may appear in many forms - in improved management in the Chesapeake Bay area and in other estuaries, in stimulation of further advance in comprehension of estuaries and the questions of adequate and excessive enrichment, in guidance for the expenditure of sufficients funds for prevention of serious problems without wastage because of ignorance, and in improved knowledge among managers, scientists and citizens concerned with achievement and maintenance of the wisest balances in our environment.

We are pleased to acknowledge many essential contributions to this volume. The authors are the most important source, followed closely by the Chesapeake Bay Program of EPA for its financial support through Grant R 806189010 and for professional support of the effort. The Planning Committee - L. Eugene Cronin, Donald R. Heinle, Andrew J. McErlean, Bruce J. Neilson and Thomas H. Pheiffer - labored productively in planning and arranging the Symposium and in assuring excellent peer review and quality control without intended injury to the freedom of the authors. Peers from many fields of science and management provided constructive review and comments on manuscripts.

Mr. Eric Rellihan worked hard and well as manager of the Symposium. Ms. Maxine Smith has been highly conscientious in preparing camera-ready copy. Ms. Linda Kilch provided intelligent assistance in preparing a Symposium brochure, advertisements of the Symposium and other useful materials. Wright Robinson performed the tedious and difficult tasks of preparing the Index. Finally, Humana Press has been most patient and courteous during completion of our material.

To these and to all of the others who participated in the Symposium, we express our sincere appreciation.

Bruce J. Neilson

L. Eugene Cronin 